\title{
Role Privilege
}

National Cancer Institute

\section{Source}

National Cancer Institute. Role Privilege. NCI Thesaurus. Code C42723.

A collection of Privilege objects. Indicates which privileges belong to this role. 